ZAPISKi HistoryCZNe t. 85, 2020, z. 1, s. 141-162

ISSN 0044-1791

http://dx.doi.org/10.15762/ZH.2020.05

MARCIN GRALA*

(iD) https://orcid.org/0000-0001-6792-0643

\title{
KILKA UWAG NA TEMAT POLITYCZNYCH OKOLICZNOŚCI MAŁŻEŃSTWA WASYla MOSKIEWSKIEgo I ZoFi WitoldóWNY ZAWARTEGO W 1391 ROKU
}

\begin{abstract}
Some Remarks on the Political Circumstances of the Marriage of Vasily I of Moscow and Sophia of Lithuania, Concluded in 1391
\end{abstract}

The marriage of Duke Vytautas the Great's daughter Sophia to the Grand Duke of Moscow Vasily in 1391 was a momentous event that impinged on the course of history. Although the circumstances in which this marriage was concluded address extremely important historical issues, such as relations between Lithuania and Moscow, Vytautas' biography, and the politics of the Grand Duchy of Moscow towards the end of the fourteenth century, historiography has not recorded many attempts to study them. This is probably due to the rather vague primary sources which are dominated by the accounts contained in the chronicles. The author of the article makes an effort to analyse them, which, combined with other evidence, as well as a review of the political situation at the time, led him to believe that it was the Moscow side that initiated the talks on the marriage of Sophia and Vasily. The Grand Duke of Moscow, Dmitry of the Don, had been looking for the possibility of a dynastic rapprochement with the ruling circles of the Grand Duchy of Lithuania for a long time. The conclusion of the Polish-Lithuanian agreement in Krevo (1385), uncertain situation in the Golden Horde and the desire to strengthen the position of his son were the reasons that could force the Moscow ruler to act more decisively in this field. Therefore, having left Tartar captivity at the end of 1385, Vasily son of Dmitri of the Don, went west, where he took the opportunity of meeting Vytautas to start first talks. The negotiations were interrupted due to a rather weak political position of Vytautas before 1389. They were resumed when it turned out that Władysław Jagiełło, after taking the throne in Kraków, did not intend to forgo his active policy in Eastern Europe. Therefore, when Vytautas fought together with the Teutonic Knights to seize power in Lithuania, Moscow decided to support his efforts. In this way, the duke, with his allies in the Teutonic Order and strong ties with Moscow, became a dangerous rival for Władysław Jagiełło. Such a turn of events could have influenced the Polish king's decision to reconcile with his cousin yet again.

Keywords: Dmitry of the Don; Vytautas the Great; Vasily I of Moscow; chronicles; relations between Lithuania and Moscow; dynastic union; Grand Duchy of Lithuania; Grand Duchy of Moscow; Golden Horde

\footnotetext{
* Instytut Historii, Uniwersytet Papieski Jana Pawła II w Krakowie, @gralamarcin@interia.pl Nadesłany 25.02.2020; Nadesłany po poprawkach 28.05.2020; Zaakceptowany 30.05.2020
} 
„Приказываю своего с(ы)на, кнАзА Васильћ, своеи кнАгинъ. А ты, с(ы)нь мои, кнАзь Василеи, чти матерь свою и слушаи своие матери в мое мъсто, своего отца"1 - tym zdaniem swego testamentu wielki książę moskiewski Wasyl I podkreślił rolę polityczną, jaką miała odegrać jego małżonka w momencie owdowienia. Córka wielkiego księcia litewskiego Witolda miała być opiekunką-regentką małoletniego następcy tronu, i to w sytuacji, gdy prawa do dziedziczenia nie były oczywiste ${ }^{2}$. Powierzenie tego zadania żonie i przede wszystkim matce następcy tronu wydaje się czymś zrozumiałym, szczególnie że od samego początku pobytu Zofii na Rusi dało się zauważyć jej niebagatelną, jak się wydaje, pozycję polityczną. Zawarty przez nią ślub z synem Dymitra Dońskiego przyczynił się do chwilowego zbliżenia Litwy i Moskwy, a znaczenie księżnej w odniesieniu do tych relacji wydaje się dość istotne. Trudno traktować jako przypadek to, że Zofia odwiedziła swego ojca w Smoleńsku w roku $1399^{3}$, gdy w stosunki między Witoldem a zięciem mogła się wkraść pewna nerwowość związana ze współpracą tego pierwszego z Tochtamyszem, chanem Złotej Ordy ${ }^{4}$. Znaczenie córki Witolda nie ograniczało się jedynie do kwestii relacji litewsko-moskiewskich, znamienne jest bowiem i to, że w 1413 r., w trakcie toczonych z zakonem krzyżackim dyplomatycznych zatargów o Żmudź, podkreślano prawa dziedziczne Zofii do spornych obszarów $^{5}$. Nie bez znaczenia jest także to, że księżna była matką jedynego wnuka

${ }^{1}$ Духовные и договорные грамоты великих и удельных князей XIV-XVI вв., Москва-Ленинград 1950 [Duchownyje $i$ dogowornyje gramoty wielikich $i$ udielnykh kniaziej $X I V-X V I$ ww., Moskwa-Leningrad 1950], s. 57-58, nr 21. Informacje na temat znanych w literaturze trzech testamentów wielkiego księcia Wasyla I w ostatnim czasie zebrał i uporządkował (uściślając ich datacje i okoliczności powstania) Władimir Kuczkin; zob. Владимир А. Кучкин, Три завещзания Василия I [Władimir A. Kuczкın, Tri zawieszczanija Wasilija I], Древняя Русь. Вопросы медиевистики [Driewniaja Rus. Woprosy miedijewistiki], 2016, nr 2 (64), s. 33-53.

${ }^{2}$ Наталья Л. Пушкарёва, Женщины древней Руси, Москва 1989 [Natalja Ł. PUszкARIоwA, Żenszcziny driewniej Rusi, Moskwa 1989], s. 49-51; Николай С. Борисов, Возвышение Mосквыl, Москва 2011 [Nikołaj S. Borisow, Wozwyszenije Moskwy, Moskwa 2011], s. 32.

${ }^{3}$ Михаил Д. Присёлков, Троицкая летопись. Реконструкция текста, Санкт-Петербург 2002 [Michaił D. PrisioŁkow, Troickaja letopis'. Rekonstruktcyja tieksta, Sankt-Pietierburg 2002], s. 449; Siergiej Polechow, Itinerarium wielkiego księcia litewskiego Witolda: 4/5 sierpnia 1392 - 2 października 1430, Rocznik Lituanistyczny, t. 5: 2019, s. 48.

${ }^{4}$ Александр И. Барбашёв, Витовть и его политика до грюнвальденской битвы (1410), Санкт-Петербургь 1885 [Aleksandr I. BARBAszow, Witowt' i jego politika do griunwaldienskoj bitwy (1410), Sankt-Pietierburg 1885], s. 96; Michał ŻDAN, Stosunki litewsko-tatarskie za Witolda, Ateneum Wileńskie, R. 7: 1930, z. 3-4, s. 545-546.

${ }^{5}$ Henryk Łowmiański, Polityka Jagiellonów, Poznań 1999, s. 117; Jan Tęgowski, Pierwsze pokolenia Giedyminowiczów, Poznań-Wrocław 1999, s. 212; Сергей Полехов, Наследники Витовта. Династическая война в Великом князнестве Литовском в 30-е годы XV века, Москва 2015 [Siergiej Polechow, Nasledniki Witowta. Dinasticzeskaja wojna w Welikom kniazżestwie Litowskom w 30-je gody XV wieka, Moskwa 2015], s. 507. 
Witolda, który dożył dorosłości, dzięki czemu władcy Moskwy mogli w przyszłości, choćby tylko symbolicznie, pretendować do roli dziedziców wielkiego Kiejstutowicza ${ }^{6}$.

Małżeństwo Zofii Witoldówny z Wasylem I miało swoją dziejową doniosłość i niebagatelne znaczenie, natomiast jego początki, kwestia pertraktacji i politycznych kalkulacji, które musiały je poprzedzać, przedstawiają się dość niejasno. Historiografia odnotowuje fakt jego zawarcia, wiążąc tę informację ze źródłowymi wzmiankami o pobycie Wasyla na Litwie po ucieczce z niewoli u Ordy, ale pytania o motywacje i oczekiwania układających się stron jak do tej pory nie doczekały się zadowalających prób wyjaśnienia. Jeśli takie bowiem podejmowano, to skupiały się one jedynie na postaci znajdującego się w tragicznej sytuacji politycznej Witolda, który próbował poprawić swoje położenie dzięki małżeństwu córki z potencjalnym dziedzicem moskiewskiego tronu? ${ }^{7}$. Tymczasem całkowite ignorowanie okoliczności, którymi mogła się kierować druga strona planowanego mariażu, nie wydaje się do końca zasadne.

Informacje o okolicznościach ślubu Zofii z Wasylem znajdują się w latopisach, które choć w wielu miejscach są niejasne, dają jednak możliwość pewnej ogólnej rekonstrukcji wydarzeń i stwierdzenia, że na przełomie 1386 i 1387 r. Wasyl uciekł z Ordy na Podole, przebywał na Wołoszczyźnie, a potem spotkał się z Witoldem ${ }^{8}$. Spośród kilku latopisarskich relacji najwięcej szczegółów pod rokiem 6894 (1385/1386) przekazuje Latopis nikonowski: „Того же льта князь Василей Дмитреевичь, внукь Иванов. Московский видя себя дрьжима во Ордъ и помысли, яко не возможно ему убъжати прямо на Русь; и умысли крЂпко сь върными своими доброхоты и побъжа вь Подольскую землю,

\footnotetext{
${ }^{6}$ Маргарита Е. Бычкова, Русско-литовская знать XV-XVII вв. Источниковедение. Генеалогия. Геральдика, Москва 2012 [Margarita Je. BYczкоwA, Russko-litowskaja znat' XV-XVII ww. Istocznikowiedienije. Gienieałogija. Gieraldika, Moskwa 2012], s. 308.

${ }^{7}$ Feliks Koneczny, Jagiełło $i$ Witold, cz. 1: Podczas unii krewskiej (1382-1392), Lwów 1893, s. 121-124; idem, Dzieje Rosji, t. 1: Do roku 1499, Komorów 2003, s. 464; Antoni ProchaSKA, Dzieje Witolda Wielkiego Księcia Litwy, Kraków 2008, s. 57-58; Ludwik KolankowsKI, Dzieje Wielkiego Księstwa Litewskiego za Jagiellonów, t. 1: 1377-1499, Oświęcim 2014, s. 60-61; Лев В. Черепнин, Образование руссково иентрализованного государства в XIV-XV веках. Очерки соииально-економической и политической истории Руси, Москва 1960 [Lew W. CZERIEPNin, Obrazowanije russkowo centralizowannogo gosudarstwa w XIV-XV wiekach. Oczerki socjalno-jekonomiczeskoj i politiczeskoj istorii Rusi, Moskwa 1960], s. 652; Grzegorz BŁaszczyк, Dzieje stosunków polsko-litewskich od czasów najdawniejszych do wspótczesności, t. 2: Od Krewa do Lublina, cz. 1, Poznań 2007, s. 128-129; Jarosław Nikodem, Witold. Wielki Książę Litewski (1354 lub 1355 - 27 października 1430), Kraków 2013, s. 113-125. O samym spotkaniu Witolda i Wasyla w roku 1387 zob. ibid., s. 119-120.

${ }^{8}$ Яков С. Лурье, Две истории Руси XV века. Ранние и поздние, независмые и официальные летописи об образовании Московского государства, Санкт-Петербург 1994 [Jakow S. ŁurJe, Dwie istorii Rusi XV wieka. Rannije i pozdnije, niezawismyje i oficyalnyje letopisi ob obrazowanii Moskowskogo gosudarstva, Sankt-Pietierburg 1994], s. 49.
} 
вь Волохи, кь Петру воеводт. И оттуду иде, вь незнаемыхь таяся, и пришедше ему вь Нъмецкую землю, и позна его князь Витовть Кестутьевичь и удержа его у себя; тогда бо бъ Витовть вь Нъмецкой земль, по убіені отца его Кестутья убъжа. Имяше же Витовть у себя дщерь едину, и сію всхоть дати за князя Василія Дмитреевичя, и глагола ему: «отпущу тя кь отцу твоему вь землю твою, аще поимеши дщерь мою за себе, единочаду сущу у мене» Онь же объщася тако сотворити, и тогда Витовть Кестутьевичь дрьжа его у себе вь чести велицъ, дондеже отпусти его кь отцу на Москву"'.

Już Andriej Ekzempljarskij zaznaczał, że przywołany fragment jest mało wiarygodny i motywacją małżeństwa Zofii i Wasyla nie był przymus, lecz polityczne zamysły. Wątku tego uczony jednak nie rozwijał, zadowalając się konkluzją, że niezależnie od okoliczności ślub tych dwojga stał się faktem ${ }^{10}$. Rzeczywiście trudno polemizować z przytoczoną opinią, wszak w źródle błędnie zaznaczono, że Witold znajdował się wówczas w Prusach. Jednak nie w tym szczególe tkwi największa wada cytowanej relacji, której ogólny przekaz jawi się jako dość niebywały. Trudno uwierzyć w to, że Wasyl został przymuszony do układów małżeńskich za cenę odzyskania wolności i powrotu do Moskwy. Nawet gdyby tak było, to przecież syn Dymitra mógł, po dotarciu do swej stolicy, całkowicie zignorować wcześniejsze deklaracje ${ }^{11}$. Choćby spisał je na pergaminie i wyrył w kamieniu, tracący swe polityczne znaczenie na Litwie Witold nie miał możliwości, by wymusić na młodzieńcu i jego ojcu wypełnie-

${ }^{9}$ Патріаршая или никоновская лптопись [Patriarszaja ili nikonowskaja lietopis'], [in:] Полное собраніе русскиихь люттописей (dalej суt. ПСРЛ), т. 11: Лютописный сборникь именуемый патриаршею или никоновскою лютописью, Санкт-Петербургь 1897, [Połnoje sobraniie russkiich' lietopisiej, t. 11: Lietopisnyj sbornik' imienujemyj patriarszeju ili nikowowskoju lietopisju, Sankt-Pietierburg' 1897], s. 90.

${ }^{10}$ Андрей В. Экземплярский, Великие и удюльные князя спверной Руси вь татарский периодь сь 1238 до 1505 г. Биографические очерки, т. 1: Великие князя владимирские и владимиро-московские, Санктпетербургь 1889 [Andriej V. EкZIEмPLJARsкIJ, Wielikije i udielnyje kniazia siewiernoj Rusi w' tatarskij pieriod' s' 1238 do 1505, t. 1: Wielikije kniazia wladimirskije i władimiro-moskowskije, Sanktpietierburg' 1889], s. 126-127. Przywołując wzmiankę Latopisu nikonowskiego, rosyjski uczony zwracał uwagę na wymowę źródła, które sugeruje, że Wasyl został przymuszony do obietnicy małżeństwa z córką Witolda siłą. Do takiej interpretacji mogą upoważniać użyte w cytowanym ustępie określenia. Zwroty „и удержа его” oraz „отпущу тя кь отцу” wskazują, że nastąpiło swego rodzaju zatrzymanie czy też przetrzymanie wbrew woli. Wymownie też wybrzmiewa umieszczony w tym fragmencie spójnik „aщe” (jeśli), który wprowadza do całej narracji pewną warunkowość. Być może A. Ekzempljarskij przesadnie pisał o siłowym przymuszeniu, jakkolwiek cytowana relacja skonstruowana została w ten sposób, by zaznaczyć, że wyrażona przez Wasyla zgoda nie była całkowicie swobodna i bezwarunkowa.

${ }^{11}$ Николай С. Борисов, Василий Темный, Москва 2020 [Nikołaj S. Borisow, Wasilij Temnyj, Moskwa 2020], s. 20. 
nie składanych obietnic ${ }^{12}$. Gdyby w Moskwie nie było woli zawarcia takiego związku, to nie podjęto by żadnych działań w celu jego realizacji. Oczywiście zasygnalizowane elementy nie upoważniają do całkowitego odrzucenia przekazu Latopisu nikonowskiego, jakkolwiek należy unikać opierania się jedynie na tym źródle.

W ostatnim czasie zagadnienie małżeństwa Zofii i Wasyla poruszone zostało w biografii Dymitra Dońskiego autorstwa Nikołaja Borisowa. Uczony, w odróżnieniu od znacznej części starszej historiografii, która moment ucieczki Wasyla sytuowała w 1386 lub $1387 \mathrm{r}^{13}$, jak najbardziej słusznie zaznaczył, że syn Dymitra opuścił Ordę 26 XI 1385 r. $^{14}$ Wskazują na to wzmianki Latopisu nikonowskiego, jak i informacje zaczerpnięte z Latopisu rogożskiego i Latopisu jermolińskiego. Ten pierwszy, przed cytowanym powyżej fragmentem uściślającym okoliczności ucieczki Wasyla z niewoli, zawiera zapis: „Тоя же осени, вь Филипово говъніе, на Юриевь день, вь недълю, побежа изо Орды оть Тахтамыша царя князь Василей Дмитреевич Московской"15. Zdanie to umieszczono także pod rokiem 6894 (1385/1386), w którym relacje skompilowano w stylu wrześniowym ${ }^{16}$. Analogiczna informacja zapisana została w zredagowanym w stylu marcowym Latopisie rogożskim pod

${ }^{12} \mathrm{O}$ marginalizowaniu swego znaczenia, na rzecz umocnienia pozycji Skirgiełły, Witold pisał w swej słynnej Skardze; zob. Dis ist Witoldes sache wedir Jagaln und Skargaln, hrsg. v. Theodor Hirsch, [in:] Scriptores rerum Prussicarum (dalej cyt. SRP), Bd. 2, hrsg. v. Theodor HiRsch, Max Töppen, Ernst Strehlкe, Leipzig 1863, s. 712-713. Najnowsza edycja: Олег Б. Лицкевич, „Летописеи, великих князей титовских” и „Повест о Подолье”. Опьт компексного критического разбора, Санкт-Петербург 2019 [Oleg B. Litskewicz, „Letopisiec wielikich kniaziej litowskikh” $i$ „Powiest o Podolje”. Opyt kompieksnogo kriticzeskogo razbora, Sankt-Pietierburg 2019], s. 263-270. Problem ten został szczegółowo omówiony m.in. w: Jarosław Nikodem, Rola Skirgiełty na Litwie do roku 1394, Scripta Minora, t. 2: 1998, s. 101-115; Jan TĘGowski, Zagadnienie władzy w Wielkim Księstwie Litewskim w okresie między unia krewska a zgonem Skirgiełty (1385-1394), Zapiski Historyczne, t. 66: 2001, z. 4, s. 7-18.

${ }^{13}$ Николай М. Карамзин, История госъцарства российскаго, т. 5, изд. 2, Санктпетербургь 1819 [Nikołaj M. KARAMzIN, Istorija gosudarstwa rossijskago, t. 5, izd. 2, Sanktpietierburg' 1819], s. 101; А. И. Барбашёв, op.cit., s. 55; F. KonecznY, op.cit., s. 121; Александр Е. Пресняковь, Образованіе великорусскаго государства. Очерк по исторіи XIII-XV столютій, Петроградь 1918 [Aleksandr E. PRIEsNiakow', Obrazowanie wielikorusskago gosudarstwa. Oczerk po istorii XIII-XV stolětiy, Pietrograd' 1918], s. 333; Лев В. Черепнин, Русские феодальные архивы XIV-XV веков, ч. 1, Москва-Ленинград 1948 [Lew W. CZERIEPNIN, Russkije fieodalnyje archiwy XIV-XV wiekow, cz. 1, Moskwa-Leningrad 1948], s. 61; idem, Обpaзование руссково, s. 650.

${ }^{14}$ Николай Борисов, Дмитрий Донской, Москва 2014 [Nikołaj Borisow, Dmitrij Donskoj, Moskwa 2014], s. 424.

${ }^{15}$ Патріаршая или никоновская, s. 86.

${ }^{16}$ Рогожский летописеи, [Rogożskij letopisiec], [in:] ПСРЛ, т. 15: Рогожский петописеи. Тверской сборник, Москва 2000 [t. 15: Rogożskij letopisiec. Twierskoj sbornik, Moskwa 2000], kol. 151. 
rokiem 6893 (1385/1386). Ten sam styl zastosowano w Latopisie jermolińskim, gdzie z kolei zapisano, że „ноября 26 [roku 6893 - M.G.] побеже изь орды князь Василеи Дмитреевичь" ${ }^{17}$. Obie zapisane w różnych stylach daty odpowiadają końcówce listopada roku $1385^{18}$.

W dalszych rozważaniach N. Borisow wyraził spore wątpliwości co do opisanej na kartach latopisów historii ucieczki Wasyla z Ordy. Młody książę, choć zapewne w otoczeniu bojarów, by udać się na Wołoszczyznę i Podole, musiał przemierzać ogromne obszary stepu. Bez mniej czy bardziej oficjalnej zgody chana było to w zasadzie niemożliwe, stąd rosyjski uczony wysnuł przypuszczenie, czy owa ucieczka nie była tylko wykonywaniem poleceń Tochtamysza, który szukał zbliżenia z Witoldem ${ }^{19}$. Wywód ten nawiązuje do wcześniejszych hipotez Igora Borysewicza Grekowa, jakoby Złota Orda, widząc wzrost potencjału polsko-litewskiego, starała się wzmocnić Ruś Północno-Wschodnią na czele z Moskwą i dlatego chan zdecydował się na wypuszczanie z niewoli książąt-zakładników ${ }^{20}$. Gdy z czasem Wasyl dotarł na obszary Wielkiego Księstwa Litewskiego, zaistniałą okoliczność postanowiły wykorzystać kręgi niezadowolone z przemian zapoczątkowanych układem krewskim. Opozycja wobec Władysława Jagiełły była spora, należeć do niej miał Witold, Moskwa, a także zakon krzyżacki i Złota Orda. Niezadowolenia z konfesyjnych przemian w Wielkim Księstwie Litewskim ukryć nie mogło także Bizancjum. Dlatego też wówczas desygnowany przez Konstantynopol na Ruś metropolita Cyprian postanowił wzmocnić opozycję wobec unii polsko-litewskiej, aranżując małżeństwo Zofii Witoldówny z przebywającym wówczas na Podolu i Wołyniu Wasylem $^{21}$. Nikołaj Borisow sygnalizując, że wywody I. B. Griekowa są słabo

${ }^{17}$ Ермолинская лптопись [Jermolinskaja lietopis'], [in:] ПСРЛ, т. 23: Ермолинская литопись, Санкт-Петербургь 1910 [t. 23: Jermolinskaja lietopis', Sankt-Pietierburg' 1910], s. 30; por. Воскресенская лютопись [Woskresenskaja lietopis'], [in:] ПСРЛ, т. 8: Продолжение тетописи по воскресенскому списку, Москва 2001 [t. 8: Prodołżenije letopisi po woskriesienskomu spisku, Moskwa 2001], s. 49.

${ }^{18}$ Лев В. Черепнин, Русская хронология, Москва 1944 [Lew W. Czeriepnin, Russkaja chronologija, Moskwa 1944], s. 31; Krzysztof Pietkiewicz, Paleografia ruska, Warszawa 2015, s. 157. Wskazane w latopisach „Филипово говение” było trwającym od 15 listopada do 25 grudnia postem poprzedzającym Boże Narodzenie. Zob. Николай Борисов, Иван III, Mocква 2000 [Nikołaj Borisow, Iwan III, Moskwa 2000], s. 105; Александр В. Лаврентьев, После Куликовской битвы. Очерки истории Окско-Донского региона в последней четверти XIV - первой четверти XVI вв., Москва 2011 [Aleksandr W. ŁaWrientjeW, Posle Kulikowskoj bitwy. Oczerki istorii Oksko-Donskogo riegiona w posledniej czetwierti XIV-pierwoj czetwierti XVIww., Moskwa 2011], s. 103.

${ }^{19}$ Н. Борисов, Дмитрий Донской, s. 424-426.

${ }^{20}$ Игор Б. Греков, Восточная Европа и упадок Золотой Орды (на рубеже XIV-XV вв.), Москва 1976 [Igor B. Grekow, Wostocznaja Jewropa i upadok Zołotoj Ordy (na rubeże $X I V-X V w w)$, Moskwa 1976], s. 179.

${ }^{21}$ Ibid., s. 189, 196-197. 
osadzone w źródłach, więc mocno hipotetyczne, uznał jednak, że tego rodzaju rekonstrukcja może wyjaśnić szereg niejasności związanych z ucieczką Wasyla z niewoli w Ordzie ${ }^{22}$.

Teorie I. B. Grekowa, rozwijane także w pracy Feliksa Szabulda ${ }^{23}$, zostały słusznie skrytykowane przez Grzegorza Błaszczyka, który wskazywał na nieprawdopodobieństwo zaistnienia tego rodzaju „egzotycznego sojuszu”, tłumacząc to chociażby różnicami religijnymi między Kościołem łacińskim a prawosławną Cerkwią ${ }^{24}$. Do spostrzeżenia poznańskiego uczonego należy dodać kolejną uwagę świadczącą na niekorzyść wywodów Grekowa. Zagadnieniu zaangażowania Cypriana w kwestię porozumienia Moskwy z Witoldem przeczą okoliczności, w jakich metropolita przebywał wówczas na obszarze Wielkiego Księstwa Litewskiego oraz podejmowane przez niego działania.

W latach osiemdziesiątych XIV w. ruska Cerkiew trawiona była poważnym sporem związanym $\mathrm{z}$ obsadą metropolitalnego tronu. W momencie ucieczki Wasyla z Ordy konflikt dotyczył dwóch pretendentów do zwierzchnictwa nad ruskim prawosławiem, którymi byli wspomniany Cyprian i popierany przez pewien czas przez Moskwę Pimen. Zamieszanie trwało już od dłuższego czasu i w celu jego zakończenia w połowie 1385 r. obu duchownych wezwano do Konstantynopola w celu ostatecznego rozsądzenia sprawy ${ }^{25}$. Jednak rozpoczęty proces przybyłego na sąd Cypriana został odroczony, gdyż

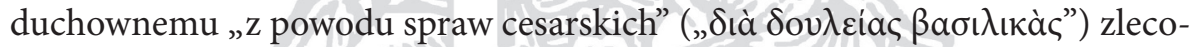
no podróż na terytorium zachodniej Rusi ${ }^{26}$. Misja spowodowana była zapewne niepokojącymi informacjami, jakie stamtąd docierały nad Bosfor. Krakowski chrzest Jagiełły pociągnął za sobą rozpoczęte z nastaniem $1387 \mathrm{r}$. aktywne działania ewangelizacyjne duchowieństwa katolickiego w Wielkim Księstwie Litewskim. Już w roku następnym starania te doprowadziły do ufundowania

${ }^{22}$ Н. Борисов, Дмитрий Донской, s. 427.

${ }^{23}$ Феликс М. Шабульдо, Земли юго западной Руси в составе Великого Княжества Литовского, Киев 1987 [Feliks M. Szabuldo, Zemli jugo zapadnoj Rusi w sostawie Wielikogo Kniażestwa Litowskogo, Kijew 1987], s. 136.

${ }^{24}$ G. BŁAszczyK, op.cit., s. 132.

${ }^{25}$ Евгений Е. Голубинский, История Русской Церкви, т. 2: Оть нашествія Монголов до митрополита Макарія включительно, ч. 1, Москва 1900 [Jewgienij E. GoŁUвIŃsкIJ, Istorija Russkoj Cerkwi, t. 1: Ot’ naszestwija Mongołow do mitropolita Makarija wkluczitielno, cz. 1, Moskwa 1900], s. 254; Антон В. Карташёв, Очерки по истории русской церкви, т. 2, Москва 1993 [Anton V. Kartaszow, Oczerki po istorii russkoj cerkwi, t. 1, Moskwa 1993], s. 332.

${ }^{26}$ Acta Patriarchatus Constantinopolitani MCCCXV-MCCCCII, t. 2, ed. Franz MikLosich, Joseph Müller, Vindobonae 1862, s. 124, nr 404; Русская историческая библиотека, т. 6: Памятники древне-русскаго каноническаго права, Санктпетербургь 1880 (dalej суt. РИБ, т. 6) [Russkaja istoriczskaja biblioteka, t. 6: Pamjatniki drewne-russkago kanoniczeskago prawa, Sanktpietierburg' 1880], kol. 215-216, nr 33. 
dobrze uposażonego biskupstwa w Wilnie ${ }^{27}$. Choć pragmatyzm polityczny nakazywał uwzględnienie specyfiki wyznaniowej kraju i prawne faworyzowanie ludności katolickiej objęło w zasadzie jedynie obszar Litwy właściwej ${ }^{28}$, trzeba przyznać słuszność zaprezentowanej przed laty przez Witolda Kamienieckiego opinii, że pierwsze przywileje Jagiełły dla katolików niosły z sobą „piętno prozelityzmu religijnego" 29 . W podobny sposób wydarzenia na Litwie mogły być interpretowane w Konstantynopolu, gdzie nie mogło też umknąć uwadze odzyskanie przez Polskę kontroli nad Rusią Halicką ${ }^{30}$. W ten sposób misja Cypriana nabierała szczególnego znaczenia, a jego spotkanie późnym latem 1387 r. z nowym polskim monarchą Władysławem Jagiełłą na wspomnianym obszarze było niemałym sukcesem ${ }^{31}$. Rozmowy z królem, który właśnie przyjął katolicyzm, były ważnym gestem, mającym dopomóc w wypracowaniu odpowiednich warunków współegzystowania w jednym państwie katolików i prawosławnych $^{32}$. Poruszanie przez Cypriana tak istotnych kwestii podaje w wątpliwość teorię, by w roku 1387 duchowny, angażując się w popieranie Witolda, podjął ryzyko pogorszenia relacji z polskim monarchą, nawet jeśli, jak sądzi Jarosław Nikodem, wspomniane pertraktacje prowadzono w sposób tajny ${ }^{33}$. Stąd nie powinno specjalnie dziwić, że choć o ucieczce Wasyla zgodnie wspominają latopisy różnej proweniencji, żaden z nich nie wzmiankuje o spotkaniu

${ }^{27}$ Tadeusz Krahel, Zarys dziejów (archi)diecezji wileńskiej, Studia Teologiczne: Białystok, Drohiczyn, Łomża, t. 5-6: 1987-1988, s. 11-13.

${ }^{28}$ Kazimierz CHODyNicki, Kościół prawosławny a Rzeczpospolita Polska. Zarys historyczny 1370-1632, Warszawa 1934, s. 84-85; Jerzy KŁoczowsкi, Młodsza Europa. Europa Środkowo-Wschodnia w kręgu cywilizacji chrześcijańskiej średniowiecza, Warszawa 1998, s. 330.

${ }^{29}$ Witold KAMIENIECKI, Ograniczenia wyznaniowe w prawodawstwie litewskim w XV i XVI w., Przegląd Historyczny, t. 13: 1911, nr 3, s. 269.

${ }^{30}$ Józef SKRzy PeK, Południowo-wschodnia polityka Polski od koronacji Jagiełty do śmierci Jadwigi i bitwy nad Worsklą (1386-1399), Oświęcim 2015, s. 27-29; H. ŁowMIAŃsKI, op.cit., s. 61; Jerzy Wyrozumski, Sprawa Rusi Halicko-Włodzimierskiej i Podola w stosunkach polsko-wegierskich wczesnej epoki jagiellońskiej, [in:] Wegry-Polska w Europie Środkowej. Historia - literatura. Księga pamiątkowa ku czci Profesora Wacława Felczaka, red. Antoni Centarowicz, Csaba G. Kiss, István Kovács, Kraków 1997, s. 45-46; G. BŁAszczyK, op.cit., s. 113-114.

${ }^{31}$ Codex diplomaticus Regni Poloniae et Magni Ducatus Lituaniae, t. 1, ed. Maciej Dogiel, Vilnae 1758, s. 597; Skarbiec diplomatów papiezkich, cesarskich, królewskich, książęcych, uchwat narodowych, postanowień różnych władz i urzędów posługujących do krytycznego wyjaśnienia dziejów Litwy, Rusi Litewskiej i ościennych im krajów, t. 1, wyd. Ignacy DaNiŁowicz, Jan SidoROWICZ, Wilno 1860, s. 270, nr 548.

${ }^{32}$ Maciej Salamon, Cyprian (Kyprianos, Kiprian) the Metropolitan of Kiev and Byzantine Policy in East-Central Europe, [in:] Byzantium and East Central Europe, ed. Günter Prinzing, Maciej Salamon, Paul Stephenson, Kraków 2001, s. 228-229; idem, Fundacja klasztoru benedyktynów słowiańskich na Kleparzu. Ekumenizm w dobie św. Królowej Jadwigi, [in:] Kościół krakowski w życiu państwa i narodu polskiego, red. Andrzej PANKowicz, Kraków 2002, s. 75-76.

${ }^{33}$ J. Niкodem, Witold, s. 119-121. 
księcia z Cyprianem, ani tym bardziej o zaangażowaniu tego ostatniego w zaaranżowanie małżeństwa $\mathrm{z}$ córką Witolda ${ }^{34}$.

Działania Tochtamysza na rzecz zbliżenia Witolda i Moskwy z powodu braku źródeł jawią się jako wątpliwe, a bezpośrednie zaangażowanie Cypriana uznać można za wręcz niemożliwe. W takiej sytuacji pozostają jedynie dwa (w zasadzie najbardziej oczywiste) możliwe wytłumaczenia podjęcia pertraktacji Wasyla z Kiejstutowiczem: albo o polityczne zbliżenie z Moskwą zabiegał Witold, albo było zupełnie odwrotnie. Wspomniane na początku trudne położenie polityczne ojca Zofii raczej wykluczało jego inicjatywę, co zresztą jest poniekąd potwierdzone źródłowo. W swojej Skardze Witold żalił się, że Jagiełło i Skirgiełło znacznie ograniczali mu możliwość swobodnego wysyłania posłańców zarówno do Prus, jak i na Ruś. W piśmie tym Kiejstutowicz podkreślił także, że nie mógł w nieskrępowany sposób decydować o małżeństwie swej córki, przy czym zaznaczył, jakoby o rękę Zofii czyniono usilne starania. Użyte w tekście sformułowanie: „[...] und man bat si von mir fil” ${ }^{35}$, zdaje się sugerować, że Witold nie był w tej kwestii stroną aktywną. W związku z tym jak najbardziej słuszna wydaje się sugestia kilkakrotnie cytowanego już N. Borisowa, że długa i ryzykowna podróż młodego Wasyla z Ordy na zachód nie mogła odbyć się bez konsultacji i zgody wielkiego księcia Dymitra ${ }^{36}$. Kierunek podróży nie był, jak to wieszczy Latopis nikonowski, próbą wprowadzenia w błąd Tochtamysza, ale świadomym manewrem podjętym w celu realizacji określonych zamierzeń politycznych.

Dywagacje na temat wyjaśnienia okoliczności ucieczki Wasyla z Ordy i jego późniejszych kontaktów z Witoldem należy rzecz jasna rozpocząć od zwrócenia uwagi na moment, w którym syn Dymitra zbiegł z niewoli. Pod koniec 1385 r. władca Moskwy zapewne miał już za sobą pierwsze wnikliwe analizy wydarzeń zachodzących na Litwie wraz z podpisaniem układu krewskiego, które musiały się spotkać z jego reakcją. Wydaje się, że błędem jest mniemanie, że Dymitr i jego otoczenie natychmiast po otrzymaniu informacji o efektach porozumienia Jagiełły z polską delegacją z przerażeniem patrzyli na wzrost potęgi polsko-litewskiej, wszak obie strony miały przed sobą sporo wyzwań, aby wypełnić wzajemne zobowiązania. Nie zmienia to oczywiście tego, że nowa rzeczywistość polityczna siłą rzeczy wymuszała na Dymitrze chęć zawarcia porozumienia. Oprócz tej ogólnej przyczyny można wymienić także inne powody, dla których Moskwa mogła dążyć do nawiązania bliższych

${ }^{34}$ Por. Сергей А. Фетищев, Московская Русь после Дмитрия Донского 1389-1395 г2., Москва 2003 [Siergiej A. FietiszCzEw, Moskowskaja Rus' posle Dmitrija Donskogo 1389-1395 gg., Moskwa 2003], s. 77.

${ }^{35}$ Dis ist Witoldes sache wedir Jagaln und Skargaln, s. 713; О. Б. Лицкевич, ор.cit., s. 266.

${ }^{36}$ Н. Борисов, Дмитрий Донской, s. 424-425. 
kontaktów z Litwą. Zanim dojdzie do ich omówienia, należy odnotować, że Dymitr Iwanowicz od dłuższego już czasu pragnął ów cel zrealizować. Przed wieloma laty Antoni Prochaska zwracał uwagę na to, że podczas krótkiego panowania Kiejstuta w latach 1381-1382 musiało dojść do bliżej nieokreślonych układów między Litwą a Moskwą, czego ślady zachowały się w późniejszych dokumentach ${ }^{37}$. Wkrótce potem, gdy na wielkoksiążęcym tronie zasiadał już Jagiełło, planowano doprowadzić do małżeństwa litewskiego hospodara z córką Dymitra - Zofią ${ }^{38}$. Zastanawiające jest, na ile podjętą przez Wasyla próbę nawiązania kontaktu z Witoldem można traktować jako pewną ciągłość działań Moskwy w odniesieniu do Litwy. Zazwyczaj starania mające na celu zabezpieczenie zachodniego pogranicza moskiewskiego władztwa tłumaczy się potrzebą skupienia uwagi na kwestii tatarskiej. Rzeczywiście, w momencie podejmowanych prób nawiązania kontaktu $z$ Witoldem sytuacja na południowo-wschodnich rubieżach Rusi zaczęła się komplikować. Po latach politycznego zamieszania w Złotej Ordzie konsolidowana przez Tochtamysza władza zagrożona była dość liczną wewnętrzną opozycją, która swe nadzieje na sukces opierała na wsparciu Timura ${ }^{39}$. Skuteczne zdławienie wrogów wewnętrznych możliwe było dopiero po pokonaniu tego wielkiego zdobywcy, który z niechęcią obserwował wzrost potęgi chana. W momencie ucieczki Wasyla z Ordy nie brakowało przesłanek wskazujących na to, że Tochtamysz szykował się do star-

${ }^{37}$ Antoni Prochaska, Upadek Kiejstuta, Kwartalnik Historyczny, t. 23: 1909, nr 4, s. 502. Lwowski uczony przywoływał m.in. układ Kazimierza Jagiellończyka z Wasylem II Moskiewskim, gdzie wspominano o przynależności włości położonych koło Osuchy do Wielkiego Księstwa Litewskiego, tak jak to było „при великомь князи Кестутьи”; Акты, относящіеия кь исторіи западной Россіи, т. 1: 1340-1506, Санктпетербургь 1846 [Akty, otnosiaszcziecia k' istorii zapadnoj Rossji, t. 1: 1340-1506, Sanktpietierburg' 1846], s. 63, nr 50. Opinię Prochaski przywołał także И. Б. Греков, ор.cit., s.140.

${ }^{38}$ Опис архива посольского приказа 1626 года, ч. 1, подгот. Валерий И. Гальцов, ред. Сигурд О. Шмидт, Москва 1977 [Opis archiwa posolskogo prikaza 1626 goda, cz. 1, podgot. Walerij I. GALCOW, red. Sigurd O. SzMIDT, Moskwa 1977], s. 34. W historiografii zwracano uwagę, że przywołany siedemnastowieczny spis nie jest chronologicznie uporządkowany. Pojawiły się różne propozycje datacji, spośród których najbardziej wiarygodne wydają się te wskazujące na lata 1383-1384. Zob. Л. Черепнин, Русские феодальные архивы, s. 50-51; Борис Н. Флоря, Договор Дмитрия Донского с Ягайло и иерковная жизнь восточной Европы [Воris N. FloRJA, Dogowor Dmitrija Donskogo s Jagajto i cerkownaja żyzn' wostocznoj Jewropy], [in:] Неисчерпаемость источника. К 70-летю В. А. Кучкина, ред. Борис Н. Флоря, Москва 2005 [Nieisczerpajemost' istocznika. K 70-letiu W. A. Kuczkina, red. Boris N. FlorJa, Moskwa 2005], s. 233-237; Jan TĘGOwski, W sprawie genezy unii Polski z Litwą. Projekt małżeństwa Jagiełly z córką Dymitra Dońskiego wielkiego księcia moskiewskiego - próba ustalenia daty, Prace Naukowe Akademii im. Jana Długosza w Częstochowie. Zeszyty Historyczne, nr 10: 2009, s. 51-64.

${ }^{39}$ Ильнур М. Миргалеев, Политическая история Золотой Орды периода павления Токтамьıи-хана, Казань 2003 [Ilnur M. Mirgalejew, Politiczeskaja istorija Zołotoj Ordy pierioda pawlenija Toktamysz-chana, Kazan’ 2003], s. 109-110. 
cia $\mathrm{z}$ dawnym protektorem. W styczniu 1385 r. posłowie władcy Złotej Ordy zjawili się w Egipcie, gdzie najprawdopodobniej szukano sojuszu przeciw Timurowi. Niewiele później Tochtamysz, opanowując Tebryz, pokrzyżował plany Timura w Azerbejdżanie ${ }^{40}$. Bezpośredni konflikt między obydwoma potężnymi władcami wydawał się nieunikniony, a jego rozstrzygnięcie - trudne do przewidzenia. Już choćby to mogło skłonić Dymitra do zbliżenia z Witoldem.

Niepozbawiona istotnego znaczenia jest także inna okoliczność, odwołująca się zresztą bezpośrednio do postaci Wasyla. Młodzieniec stawał się coraz starszy i w Moskwie, mimo że Dymitr wciąż był w sile wieku, musiały się pojawiać pierwsze myśli o przekazaniu mu władzy. Tymczasem nie było pewności, jak zachowa się mający nad wyraz dobre powiązania dynastyczne z Olgierdowiczami, stryjeczny brat moskiewskiego władcy - Włodzimierz Sierpuchowski ${ }^{41}$. Latopisy wspominają o tym, że na początku 1389 r. między krewniakami doszło do poważnego sporu ${ }^{42}$. Dawniej sądzono, że konflikt związany był ze sprzeciwem księcia z Sierpuchowa wobec planów przekazania władzy w Moskwie z ojca na syna ${ }^{43}$. Nowsze badania dowiodły, że konflikt Dymitra Iwanowicza z Włodzimierzem miał zupełnie inne podłoże, gdyż kwestia następstwa tronu z ojca na syna pośród potomków Iwana Kality stawała się pewną normą. Przyczyną konfliktu był problem dość licznego potomstwa Dymitra Iwanowicza, który zorientował się, że nie jest w stanie wydzielić synom odpowiednio dużych udziałów. Z tego też powodu zdecydował się na odebranie stryjecznemu bratu Galicza i Dymitrowa, tak aby Włodzimierz w przyszłości nie dominował nad jego potomkami ${ }^{44}$. O wybuchu konfliktu źródła wzmiankują pod rokiem 1389, gdy władca Moskwy zainicjował nieakceptowane przez księcia sierpuchowskiego działania. Jednak myśl o tych posunięciach mogła pojawić się wcześniej, być może już latem 1385 r., gdy Dymitrowi urodził się kolejny syn - Piotr ${ }^{45}$. Już wtedy wielki książę wiedział, że będzie musiał wydzielić potomkom cztery udziały. Podejmując próbę pomniejszenia władztwa Włodzimierza Sierpuchowskiego, Dymitr musiał się spodziewać jego wrogiej reakcji.

${ }^{40}$ Borys Grekow, Aleksandr Jakubowski, Złota Orda i jej upadek, tł. Władysław GŁucноwsкi, Warszawa 1953, s. 264-265; Роман Ю. Почекаев, Цари ордынские. Биографии ханов и правителей Золотой Орды, Санкт-Петербург 2010 [Roman Ju. PoczeкAJEw, Cari ordynskije. Biografii chanow i prawitielej Zołotoj Ordy, Sankt-Pietierburg 2010], s. 167.

${ }^{41}$ Jego żoną była córka Olgierda i Julianny, czyli siostra Jagiełły - Helena. Zob. J. TęGowski, Pierwsze pokolenia, s. 124.

${ }^{42}$ Рогожский летописеи, kol. 155; М. Д. Присёлков, Троиикая летопись, s. 433.

${ }^{43}$ Сергей М. Соловьёв, Древнерусские князя, Санкт-Петербург 2010 [Siergiej M. SoŁowjow, Driewnierusskije kniazia, Sankt-Pietierburg 2010], s. 279; А. В.Экземплярский, op.cit., s. 121.

${ }^{44}$ Zob. nowszą literaturę w: С. А. Фетищев, Московская Русь, s. 37-43.

${ }^{45}$ М. Д. Присёлков, Троицкая летопись, s. 429. 
Wzmocnienie pozycji najstarszego syna dzięki małżeństwu z córką Witolda mogło zaś zrównoważyć dynastyczne powiązania Włodzimierza.

Zagadnieniem niezwykle istotnym pozostaje wyjaśnienie, dlaczego zabiegi Moskwy skierowano właśnie w stronę Witolda, a nie jednego z braci Władysława Jagiełły. Można założyć, że zbliżenie Moskwy z Witoldem było obliczone na wzmocnienie pozycji Kiejstutowicza i ponowne rozbudzenie separatyzmu między obydwoma stryjecznymi braćmi. Jednak słuszność tego rozumowania odpowiada raczej rzeczywistości nieco późniejszej, gdy sytuacja wewnętrzna na Litwie, w tym położenie samego Witolda, stała się jasna dla wszystkich potencjalnych obserwatorów tamtejszych wydarzeń. Zastanawiające jest zatem, jak w Moskwie na bieżąco interpretowano zachodzące na Litwie przemiany i jakie wnioski można było wówczas wysuwać. Zachowane w latopisarstwie Rusi Północno-Wschodniej wzmianki o Litwie, choć w wielu miejscach nieprecyzyjne, wskazują na to, że bacznie przyglądano się wypadkom zachodzącym u zachodniego sąsiada. Pośród szeregu odnotowanych przez kompilatorów relacji na temat Litwy ważne miejsce zajmowały informacje o wydarzeniach, jakie nastąpiły po śmierci Olgierda, czyli wzmianki o wojnie Jagiełły z Kiejstutem, determinacji Witolda i wreszcie objęciu przez litewskiego hospodara polskiego tronu ${ }^{46}$. Nie można wykluczyć, że następujące po sobie fakty mogły w Moskwie wywołać wrażenie, że w nowym układzie utrzymane zostaną stare zasady funkcjonowania władzy na Litwie. Za czasów Olgierda i Kiejstuta obaj Giedyminowicze ściśle ze sobą współpracowali, dzieląc się sprawowaną wła$\mathrm{dza}^{47}$. Gdy Jagiełło został polskim królem, można było się spodziewać, że energiczny, niedający za wygraną syn Kiejstuta będzie zarządzał Litwą. W zasadzie nie mogło być inaczej, skoro sam Witold, lepiej zorientowany w uwarunkowaniach politycznych w Wielkim Księstwie Litewskim, był rozczarowany i nie krył swej goryczy wywołanej słabą pozycją polityczną ${ }^{48}$. Zatem jeśli Kiejstuto-

${ }^{46}$ Siergiej Polechow, Wielkie Księstwo Litewskie i Królestwo Polskie za czasów Jagiełly i Witolda w latopisarstwie ruskim, Zeszyty Naukowe Uniwersytetu Jagiellońskiego. Prace Historyczne, nr 141: 2014, z. 2, s. 589-590.

${ }^{47}$ Jak wykazał J. Nikodem, trudno szukać wiarygodnych dowodów źródłowych potwierdzających funkcjonowanie prawnie unormowanej diarchii na Litwie. Nie zmienia to faktu, że długa i korzystna dla Wielkiego Księstwa Litewskiego współpraca Olgierda i Kiejstuta upoważnia do mówienia o współrządach obu braci, co siłą rzeczy wynosiło księcia trockiego ponad innych dynastów. Zob. Jarosław Niкodem, Jedynowładztwo czy diarchia? Przyczynek do dziejów ustroju Wielkiego Księstwa Litewskiego do końca XIV w., Zapiski Historyczne, t. 68: 2003, z. 4, s. 27. Podobnie przed wieloma laty wypowiadał się Antoni Prochaska, Przyczynki krytyczne do dziejów Unii, Rozprawy Akademii Umiejętności. Wydział Historyczno-Filozoficzny, t. 33: 1896 , s. 59-61.

${ }^{48},[\ldots]$ und herczog Jagal siner truwe nicht derfollete und trat ab siner warheit und myn fetirlich erbe gab her mir nicht und myn fetirlich erbe gab her synem bruder herczogen Skirgal"; Dis ist Witoldes sache wedir Jagaln und Skargaln, s. 713; А. И. Барбашёв, ор.cit., s. 47; 
wicz oczekiwał po swym pojednaniu z Jagiełłą znacznie więcej, to o ileż bardziej mógł się tego spodziewać chociażby Dymitr Iwanowicz.

Wskazanie kilku wymienionych tu przyczyn, które mogły skłaniać Moskwę do zbliżenia z Witoldem nie przesądza oczywiście o tym, że małżeństwo Zofii z Wasylem było realizacją usilnych planów Dymitra. Jednak wspomniana bierność czy też brak możliwości działania Witolda powodują, że inicjatywa ze strony Moskwy wydaje się prawdopodobna. Przemawiać za tym może latopisarska informacja dotycząca wysłania przez Dymitra posłów, którzy mieli przyspieszyć powrót Wasyla do Moskwy. Wzmianka ta znajduje się w tych latopisach, które nie przybliżają okoliczności pertraktacji małżeńskich między Witoldem a Dymitrowiczem, informując jedynie o ucieczce tego ostatniego z Ordy na zachód. W części z latopisarskich relacji zapisano, że książę moskiewski wysłał swoich „starszych bojarów”, którzy udali się po Wasyla do ziemi połockiej. Taki zapis znajduje się m.in. w latopisach z grupy rogożsko-symeonowskiej ${ }^{49}$, której protograf bazuje na dokonanej w 1412 r. twerskiej redakcji zwodu roku $1408^{50}$. Istnieją jednak latopisy, w których z kolei zapisano, że posłowie Dymitra pojechali do ziemi podolskiej. Wygląda to na efekt zwykłej, zaistniałej na etapie przepisywania zwodów i prac redakcyjnych, pomyłki. Ostateczne rozstrzygnięcie, która z relacji jest bliższa prawdy, jeśli w ogóle jest możliwe, wymaga zapewne niełatwego, gruntownego studium tekstologicznego, do którego przeprowadzenia autor niniejszego tekstu nie czuje się odpowiednio przygotowany. W tym jednak miejscu warto zwrócić uwagę na dość ważną okoliczność, która przemawia za wersją o ziemi podolskiej. Tego rodzaju wzmiankę zawierają Latopisarski zwód roku $1497^{51}$ oraz bazujące na nim:

Henryk Paszkiewicz, O genezie i wartości Krewa, Warszawa 1938, s. 174-175; G. B£Aszczyк, op.cit., s. 128; Robert Frost, Oksfordzka historia unii polsko-litewskiej, t. 1: Powstanie i rozwój 1385-1569, tł. Tomasz Fiedorek, Poznań 2018, s. 132-133. Jarosław Nikodem nie do końca zgadza się z teorią, jakoby pojednanie Witolda z Jagiełłą obwarowane było obietnicą zwrotu Trok. Poznański uczony podkreśla, że w owym czasie w relacjach między braćmi stryjecznymi to Kiejstutowicz był petentem i „zgadzając się na powrót, brał to, co mu obiecywano”; J. NikoDEM, Witold, s. 91. Być może rzeczywiście tak było, choć w mojej opinii niełatwo to udowodnić, a wymowa źródła jawi się dość jednoznacznie. Autor biografii Witolda wskazuje, że informując o obietnicy oddania Trok, książę mógł się pokrętnie tłumaczyć z pierwszej zdrady Krzyżaków. Nie jestem do końca przekonany, czy ten sposób rozumowania jest zasadny, wszak Krzyżacy byli dość dobrze zorientowani w sprawach litewskich, by zadowolić się tego rodzaju wymówką.

${ }^{49}$ Rok 6895 (1387/1388): „Тое же осени князь великій Дмитреи Ивановичь отьпусти боярь своих старъишихь противу сыну своему князю Василью вь Полотскую землю [wyróżnienie - M.G.]"; Рогожский летописеи, kol. 153.

${ }^{50}$ Словарь книжников и книжности древней Руси, вып. 2, ч. 2, ред. Дмитрий С. Лихачев, Ленинград 1989 [Stowar' kniżnikow i kniżnosti driewniej Rusi, wyp. 2, cz. 2, red. Dmitry S. LichaCZEW, Leningrad 1989], s. 22-23.

${ }^{51}$ „Князь великии посла старъиших бояр по князя Василия в Подольскую землю [wyróżnienie - M.G.]"; Летописный свод 1479 z. [Letopisnyj swod 1479g.], [in:] ПСРЛ, т. 28: 
Moskiewski zwód końca XV w. $^{52}$, Latopis jermoliński ${ }^{53}$ oraz Latopis woskrieseń$s k i^{54}$. W części zawierającej opis tych wydarzeń wymienione źródła oparte są na protografie będącym przeredagowaną wersją zwodu roku 1448. Jak wykazał Jakow Łurje, kompilator pracujący na zwodzie roku 1448 miał na celu oczyszczenie tekstu z maniery poprzednika, który redagując latopisarskie informacje w okresie walk dynastycznych podczas tzw. wojny feudalnej, koniecznie chciał stworzyć latopis o neutralnym nastawieniu do opisywanej rzeczywistości. Stąd w zasadniczym zwodzie roku 1448 było sporo opuszczeń z poprzednich tradycji latopisarskich. Pracujący w latach sześćdziesiątych i siedemdziesiątych XVw. kompilator przeróbki tego tekstu ochoczo sięgał więc do oryginalnego zwodu roku 1408, uwypuklając przede wszystkim informacje o charakterze wielkoksiążęcym ${ }^{55}$. Okoliczności te sprawiają, że w tym przypadku informacje przekazywane przez Latopisarski zwód roku 1497 mogą być bardziej wiarygodne niż te zapisane w latopisach grupy rogożsko-symeonowskiej. Jeśli prawdą jest, że posłańcy Dymitra zostali oddelegowani właśnie na Podole, skąd według relacji Latopisu nikonowskiego Wasyl dopiero udawał się do Witolda, to oznacza to, że cały układ małżeński był aranżowany przez Moskwę i dokonywał się z udziałem „starszych bojarów” moskiewskiego władcy.

Obecność doradców, którzy towarzyszyli Wasylowi w drodze na Wołoszczyznę i Podole, oraz dołączenie się do nich przysłanych z Moskwy bojarów nie powinno specjalnie dziwić. Wątpliwe jest bowiem to, by Dymitr Iwanowicz mógł pozostawić kwestię małżeństwa syna przypadkowi. Co prawda sam, szybko osierocony ${ }^{56}$, w kwestii swojego małżeństwa był samodzielny, ale zawarty przez niego sakramentalny związek z córką księcia suzdalskiego Eudoksją bezsprzecznie miał wymiar polityczny ${ }^{57}$. Podobnie wydanie córki Zofii

Летописный свод 1479 г. Летописный свод 1518 г. (Уваровская летопись), Москва-Ленинград 1962 [t. 28: Letopisnyj swod 1479 g. Letopisnyj swod 1518 g. (Uwarowskaja letopis'), Moskwa-Leningrad 1962], s. 85.

${ }^{52}$ Московский тетописный свод кониа XV века [Moskowskij letopisnyj swod koonca XV wieka], [in:] ПСРЛ, т. 25: Московский летописный свод конца XV века, Москва-Ленинград 1949 [t. 25: Moskowskij letopisnyj swod koonca XV wieka, Moskwa-Leningrad 1949], s. 214.

${ }^{53}$ Ермолинская лютопись, s. 130.

${ }^{54}$ Воскресенская лтпооись, s. 52.

55 Яков С. Лурье, Московский свод 1479 года и его npomorpaø [Jakow S. ŁurJe, Moskowskij swod 1479 goda i jego protograf], Труды Отдела древнерусской литературы [Trudy Otdela drewnierusskoj literatury], t. 30: 1976, s. 105-106.

${ }^{56}$ Ojciec urodzonego w 1350 r. Dymitra, Iwan Iwanowicz, zmarł, gdy chłopiec miał dziewięć lat, a matka odeszła niespełna pięć lat później. O rodzicach Dymitra Iwanowicza zob. Н. Борисов, Дмитрий Донской, s. 14-18.

${ }^{57}$ Владимир А. Кучкин, Русские княжества и земли перед куликовской битвой [Włаdimir A. Kuczкın, Russkie kniażestwa i ziemli pieried kulikowskoj bitwoj], [in:] Куликовская битва. Сборник статей, ред. Любомир Г. Бескровный, Москва 1980 [Kulikowskaja bitwa. Sbornik statiej, red. Ljubomir G. Bieskrowny,, Moskwa 1980], s. 66-68. 
za Fiodora, syna Olega Riazańskiego, podyktowane było zaistniałą koniunkturą polityczną i chęcią trwałego pojednania $\mathrm{z}$ Riazaniem ${ }^{58}$.

Jakkolwiek w szczegółach wyglądały rozmowy w sprawie małżeństwa Zofii z Wasylem, zastanawiające jest to, dlaczego jego realizacja została odsunięta w czasie. Problematyczny mógł być wiek Zofii, która wedle ustaleń Jana Tęgowskiego urodziła się ok. 1375 r. $^{59}$, co oznacza, że w momencie podejmowanych rokowań małżeńskim mogła mieć ok. 12 lat. Wedle praktykowanych na Rusi zwyczajów i przepisów cerkiewnych córka Witolda ledwie osiągnęła wiek wystarczający do zawarcia małżeństwa albo dopiero się do niego zbliżała ${ }^{60}$. Najprawdopodobniej jednak posłowie moskiewscy na miejscu zorientowali się, jaka jest prawdziwa pozycja Witolda na Litwie i plany zostały wstrzymane. Być może też o pertraktacjach dość szybko dowiedzieli się Władysław Jagiełło ze Skirgiełłą, którzy uniemożliwili prowadzenie dalszych rozmów na temat małżeństwa. W tym kontekście nieco jaśniej wygląda niezwykle interesujące, czy wręcz intrygujące zdanie latopisów o powrocie Wasyla do Moskwy. W dniu 19 I 1388 r. (styczeń marcowego roku 6895) zapisano: „пріиде кь своему отцу кь князю кь великому, князь Василеи Дмитріевичь, а с нимь князи Лят-

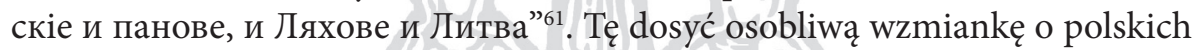
dygnitarzach nawiedzających wówczas Moskwę można wytłumaczyć tym, że Wasylowi towarzyszyło poselstwo Władysława Jagiełły, który zakomunikował Dymitrowi, że jeśli chce pertraktować w sprawie małżeństwa jego syna z córką Witolda, to w pierwszej kolejności powinien uzgodnić to z nim. Sprawa małżeństwa Wasyla z córką Kiejstutowicza znalazła się w zawieszeniu.

Gdy próbowano aranżować małżeństwo Wasyla z córką Witolda, w Wielkim Księstwie Litewskim swoje polityczne znaczenie całkowicie utracił człowiek, którego w Moskwie można było postrzegać jako orędownika interesów ruskich. Wiosną 1387 r. Andrzej Połocki, niedawny bohater znad Donu, który u boku Dymitra Iwanowicza zadał klęskę wojskom Mamaja, został pozbawiony swej dzielnicy i na długie lata stał się więźniem chęcińskiego zamku².

${ }^{58}$ Дмитрий Иловайский, История Рязанского Княжества, Москва 1858 [Dmitrij IŁowAJskiJ, Istoria Riazanskogo Kniażestwa, Moskwa 1858], s. 181-182; А. В. Лаврентьев, ор.cit., s. 101 (w tekście błędnie podano datę małżeństwa).

${ }^{59}$ J. Tęgowski, Pierwsze pokolenia, s. 212.

${ }^{60} \mathrm{Na}$ początku XV w. metropolita Focjusz pisał do Nowogrodu i Pskowa pisma, w których napominał, aby przestrzegać prawa kościelnego. Pośród szeregu przepisów duchowny wskazywał także na zakaz wydawania za mąż dziewcząt, które nie osiągnęły 12 roku życia. Zob. РИБ, т. 6, kol. 275, nr 33; ibid., kol. 284, nr 34. Oczywiście zasada ta nie była bezwzględnie przestrzegana (inaczej metropolita nie musiałby o niej przypominać), szczególnie gdy w grę wchodziły ważne kwestie polityczne. Por. Н. Л. Пушкарёва, op.cit., s. 75.

${ }^{61}$ Рогожский летописеи, kol. 153; М. Д. Присёлков, Троицкая летопись, s. 432.

${ }^{62}$ Wanda Maciejewska, Dzieje ziemi połockiej w czasach Witołda, Ateneum Wileńskie, R. 8: 1933, s. 10; J. TęGowski, Pierwsze pokolenia, s. 70. 
Wkrótce potem w czasie polowań w lasach skojsterskich Władysław Jagiełło przyznał Skirgielle księstwo trockie, Połock i szereg innych ziem Wielkiego Księstwa Litewskiego ${ }^{63}$. Te obfite nadania uczyniły z królewskiego brata faktycznego zarządcę Litwy ${ }^{64}$, a jego dotychczasowa wierność i oddanie monarsze wskazywały, że w Wilnie będzie kontynuowana polityka z czasów panowania Jagiełły jako wielkiego księcia litewskiego. Na Litwie przebywali wówczas Wasyl i posłowie Dymitra. Obserwacja rzeczywistości kazała więc zweryfikować dotychczasowe przewidywania i skłaniała do przekonania, że Jagiełło, od młodości przeznaczony do władzy syn Olgierda ${ }^{65}$, nawet $\mathrm{z}$ dalekiego Krakowa będzie w sprawach wschodnich kontynuował politykę ojca. Pierwsze polityczne kroki wykonane w tym kierunku po zawarciu umowy krewskiej zdawały się te obawy potwierdzać. Realizowane w latach 1387-1388 działania mające na celu wyeliminowanie Andrzeja Połockiego, a potem zhołdowanie Dymitra Brańskiego i podporządkowanie Litwie Smoleńska zachęciły Jagiełłę do znacznie ambitniejszych ruchów. W 1388 r. do Nowogrodu wysłano Semiona Lingwena, który przed udaniem się nad Wołchow złożył w Sandomierzu przysięgę wierności królowi, królowej i Koronie. Tak śmiała próba rozszerzenia wpływów litewsko-polskich na północy z pewnością zaniepokoiła Moskwę ${ }^{66}$. Zapewne nie bez satysfakcji więc przyjęto tam informacje o nowych konfliktach wewnętrznych na Litwie, które zahamowały dalsze działania Władysława Jagiełły na Rusi. Przed polskim monarchą stanął poważny problem powtórnej zdrady Witolda ${ }^{67}$.

Rozpoczęty pod koniec 1389 r. drugi okres współdziałania Witolda z Krzyżakami świadczył o jego determinacji, co w połączeniu z talentem politycznym, dynastyczną przynależnością i niewątpliwym poparciem części bojarów litewskich ${ }^{68}$ stanowiło przesłanki na tyle skuteczne, by w Moskwie podjęto decyzję o urzeczywistnieniu małżeńskich planów sprzed niespełna dwóch lat. Patrząc na wydarzenia na Litwie z perspektywy moskiewskiej, można było oczekiwać, że syn Kiejstuta, który w odróżnieniu od Olgierda za priorytetowe

${ }^{63}$ Codex epistolaris saeculi decimi quinti, t. 1, ed. August SokoŁowski, Józef Szujski, Cracoviae 1876, s. 9-10, nr 9.

${ }^{64}$ A. Prochaska, Dzieje Witolda, s. 55; Jadwiga Krzyżaniakowa, Jerzy Ochmański, Władysław II Jagiełło, Wrocław-Warszawa-Kraków 2006, s. 122, 125.

${ }^{65}$ Por. Stefan M. Kuczyński, Król Jagiełło ok. 1351-1434, Katowice 1985, s. 28; J. KRZyżANIAKOWA, J. OCHMAŃsKi, op.cit., s. 56.

${ }^{66}$ Oskar Halecki, Dzieje unii jagiellońskiej, t. 1: W wiekach średnich, opr. Katarzyna BŁACHOwsKA, Warszawa 2013, s. 128, 130-131; H. ŁowMIAŃski, op.cit., s. 167-168. O wyraźnie antymoskiewskim charakterze polityki Jagiełły i Skirgiełły w kontekście ślubu Wasyla i Zofii pisze m.in. L. Kolankowski, op.cit., s. 61.

${ }^{67}$ Wigand von Marburg, Nowa kronika pruska, opr. Sławomir Zonenberg, Krzysztof KWIATKOWSKi, Toruń 2017, s. 540-543.

${ }^{68}$ G. BŁAszczyK, op.cit., s. 35. 
działania uznawał walkę z zakonem krzyżackim, a nie aktywność na wschodzie $^{69}$, będzie dla Moskwy władcą znacznie bardziej pożądanym niż Jagiełło i jego współpracownicy. Nie przypadkiem więc decyzja o realizacji małżeństwa Wasyla z Zofią podjęta została właśnie w momencie, gdy Jagiełło ujawnił swoje plany w kwestii Nowogrodu, a sprawa jego głównego rywala na Litwie, jakim po spacyfikowaniu Andrzeja Połockiego był Witold, wymagała zdecydowanego wsparcia. Była to w zasadzie jedyna możliwość powstrzymania coraz śmielszej polityki wschodniej Władysława Jagiełły ${ }^{70}$.

Wraz z końcem lata 1390 r. do Prus przybyło poselstwo Wasyla, które zorganizowało przyjazd Zofii do Moskwy. Córka Witolda udała się na Ruś okrężną drogą, tak aby ominąć Litwę, co najlepiej dowodzi tego, jak niemiły Władysławowi Jagielle musiał był planowany związek. Zofia wyruszyła z Malborka do Gdańska i wsiadła na statek kierujący się dalej na północ. Następnie przez Psków dotarła do celu, gdzie Wasyl przywitał ją z wielką czcią i rozpoczęto przygotowania do ślubu ${ }^{71}$. Jak podaje Latopis troicki, 9 I 1391 r., „Вь недЂлю на память святого мученика Поліекта, оженися князь велики Василеи Дмитріевич у князя у великаго у Витовта у Кестутьевичя у Литовскаго, поя дщерь его, нареченную вь святомь крещеніи Coфію"72. Realizacja małżeństwa Zofii z Wasylem spowodowała, że pojawiło się bardzo poważne niebezpieczeństwo współdziałania Moskwy i Krzyżaków przeciwko polityce Władysława Jagiełly, czego ten z pewnością był świadom i czego na pewno się obawiał ${ }^{73}$. Zwornikiem tego niekorzystnego dla polskiego monarchy układu był walczący u boku zakonu krzyżackiego Witold, który od 1391 r. stał się teściem Wasyla Moskiewskiego. Tego rodzaju okoliczności zmobilizowały króla do podjęcia próby pojednania z Kiejstutowiczem, czego efektem stała się zawarta w 1392 r. ugoda ostrowska ${ }^{74}$. Kto wie, czy nie był to pierwszy tak poważny skutek polityczny wywołany małżeństwem Zofii z Wasylem.

${ }^{69}$ Stephen C. Rowell, Pogańskie imperium. Litewska dominacja w Europie Środkowo-Wschodniej 1295-1345, tł. Grzegorz SmóŁKA, Oświęcim 2017, s. 290; J. TęGowski, Pierwsze pokolenia, s. 198.

${ }^{70}$ С. А. Фетищев, Московская Русь, s. 85-86.

${ }^{71}$ Johanns von Posilge, Officials von Pomesanien Chronik des Landes Preussen (von 1360 an, fortgesetzt bis 1419), hrsg. v. Ernst Strehlke, [in:] SRP, Bd. 3, hrsg. v. Theodor Hirsch,

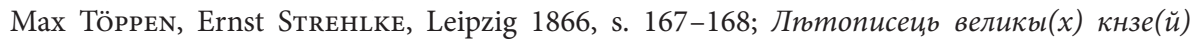
литовьскы (x). Супрасльскій списокь [Letopisiec' wieliky(ch) knzie(j) litow'sky(ch). Supraslskij spisok'], [in:] ПСРЛ, т. 17: Западнорусские летописи, Москва 2008 [t. 17: Zapadnorusskije letopisi, Moskwa 2008], kol. 80. Szczegółowe informacje o przekazie latopisów o proweniencji litewskiej zob. О. Б. Лицкевич, ор.cit., s. 526-528.

${ }^{72}$ М. Д. Присёлков, Троицкая летопись, s. 436.

${ }^{73}$ А. И. Барбашёв, ор.cit., s. 55-56; С. А. Фетищев, Московская Русь, s. 85.

${ }^{74}$ Akta unji Polski z Litwa, 1385-1791, wyd. Stanisław KutrzebA, Władysław Semkowicz, Kraków 1932, s. 26-27, nr 29. 


\section{Bibliografia}

Akty, otnosyashchietsya k' istorii zapadnoy Rossii, vol. 1: 1340-1506. Sanktpeterburg': Tipografiya II Ot'deleniya Sobstvennoy Ye. I. V. Kantselyarii, 1846.

Barbashëv, Aleksandr I. Vitovt' i yego politika do gryunval'denskoy bitvy (1410). Sankt-Peterburg': Tipografiya N. I. Skorokhodova, 1885.

Błaszczyk, Grzegorz. Dzieje stosunków polsko-litewskich od czasów najdawniejszych do współczesności, vol. 1: Od Krewa do Lublina, part 1. Poznań: Wydawnictwo Poznańskie, 2007.

Borisov, Nikolay. Dmitriy Donskoy. Moskva: Molodaya Gvardiya, 2014.

Borisov, Nikolay. Ivan III. Moskva: Molodaya Gvardiya, 2000.

Borisov, Nikolay. Vasiliy Temnyy. Moskva: Molodaya Gvardiya, 2020.

Borisov, Nikolay. Vozvysheniye Moskvy. Moskva: Russkiy Mir', 2011.

Bychkova, Margarita. Russko-litovskaya znat' XV-XVII vv. Istochnikovedeniye. Genealogia. Geral'dika. Moskva: Kvadriga, 2012.

Cherepnin, Lev. Obrazovaniye russkovo tsentralizovannogo gosudarstva $v X I V-X V$ vekakh. Ocherki sotsial'no-yekonomicheskoy i politicheskoy istorii Rusi. Moskva: Izdaltel'stvo sotsial'no-ekonomichshchskoy literatury, 1960.

Cherepnin, Lev. Russkaya khronologiya. Moskva: Glavnoye Arkhivnoye Upravleniye NKVD SSSR, 1944.

Cherepnin, Lev. Russkiye feodal'nyye Arkhivy XIV-XV vekov, vol. 1. Moskva, Leningrad: Izdatel'stvo Akademii Nauk SSSR, 1948.

Chodynicki, Kazimierz. Kościót prawosławny a Rzeczpospolita Polska. Zarys historyczny 1370-1632. Warszawa: Instytut Popierania Nauki, 1934.

Daniłowicz, Ignacy and Jan Sidorowicz, eds. Skarbiec diplomatów papiezkich, cesarskich, królewskich, książęcych, uchwał narodowych, postanowień różnych władz i urzędów posługujących do krytycznego wyjaśnienia dziejów Litwy, Rusi Litewskiej i ościennych im krajów, vol. 1. Wilno: A. H. Kirkor, 1860.

Dukhovnyye i dogovornyye gramoty velikikh i udel'nykh knyazey XIV-XVI vv. Moskva, Leningrad: Izdatels'stvo Akademii Nauk SSSR, 1950.

Ekzempyarskiy, Andrey V. Velikiye i uděl'nyye knyazya sěvernoy Rusi v' tatarskiy period' s' 1238 do 1505, vol. 1: Velikiye knyazya vladimirskiye i vladimiro-moskovskiye. Sanktpeterburg': Tipografiya Imperatorskoy Akademii Nauk', 1889.

Fetishczev, Sergey. Moskovskaya Rus' posle Dmitriya Donskogo 1389-1395 gg. Moskva: Drevlekhranilishche, 2003.

Florya, Boris. “Dogovor Dmitriya Donskogo s Yagaylo i tserkovnaya zhizn’ vostochnoy Yevropy." In Neischerpayemost' istochnika. K 70-letyu V. A. Kuchkina, edited by Boris Florya, 233-237. Moskva: Izdatel'stvo "Pamyatniki istoricheskoy mysli", 2005.

Frost, Robert. Oksfordzka historia unii polsko-litewskiej, vol. 1: Powstanie i rozwój 1385-1569. Translated by Tomasz Fiedorek. Poznań: Dom Wydawniczy Rebis, 2018.

Gal'tsov, Valeriy and Sigurd Shmidt, eds. Opis arkhiva posol'skogo prikaza 1626 goda, vol. 1. Moskva: Tsentral'nyy Gosudarstvennyy Arkhiv Drevnikh Aktov, Arkheograficheskaya komissiya pri Otdelenii istorii AN SSSR, 1977. 
Golubinskiy, Yevgeniy. Istoriya Russkoy Tserkvi, vol. 2: Ot' nashestviya Mongolov do mitropolita Makariya vklyuchitel'no. Moskva: Universitetskaya tipografiya, 1900.

Grekov, Igor. Vostochnaya Yevropa i upadok Zolotoy Ordy (na rubezhe XIV-XV vv.). Moskva: Nauka, 1976.

Grekow, Borys and Aleksandr Jakubowski. Złota Orda i jej upadek. Translated by Władysław Głuchowski. Warszawa: Książka i Wiedza, 1953.

Halecki, Oskar. Dzieje unii jagiellońskiej, vol. 1: W wiekach średnich. Edited by Katarzyna Błachowska. Warszawa: Wydawnictwo Neriton, 2013.

Hirsch, Theodor, ed. "Dis ist Witoldes sache wedir Jagaln und Skargaln." In Scriptores rerum Prussicarum, vol. 2, edited by Theodor Hirsch, Max Töppen and Ernst Strehlke, 712-714. Leipzig: S. Hirzel, 1863.

Ilovayskiy, Dmitriy. Istoriya Ryazanskogo Knyazhestva. Moskva: Universitetskaya Tipografiya, 1858.

Kamieniecki, Witold. "Ograniczenia wyznaniowe w prawodawstwie litewskim w XV i XVI w." Przeglad Historyczny 13/3 (1911): 268-282.

Karamzin, Nikolay. Istoriya gosydarstva rossiyskago, vol. 5. Sanktpeterburg': Tipografiya N. Grecha, 1819.

Kartashëv, Anton. Ocherki po istorii russkoy tserkvi, vol. 1. Moskva: Terra, 1993.

Kłoczowski, Jerzy. Młodsza Europa. Europa Środkowo-Wschodnia w kregu cywilizacji chrześcijańskiej średniowiecza. Warszawa: Państwowy Instytut Wydawniczy, 1998.

Kolankowski, Ludwik. Dzieje Wielkiego Księstwa Litewskiego za Jagiellonów, vol. 1: 1377-1499. Oświęcim: Napoleon V, 2014.

Koneczny, Feliks. Dzieje Rosji, vol. 1: Do roku 1499. Komorów: Wydawnictwo Antyk Marcin Dybowski, 2003.

Koneczny, Feliks. Jagiełło i Witold, vol. 1: Podczas unii krewskiej (1382-1392). Lwów: nakł. aut., 1893.

Krahel, Tadeusz. “Zarys dziejów (archi)diecezji wileńskiej.” Studia Teologiczne: Białystok, Drohiczyn, Łomża 5-6 (1987-1988): 7-72.

Krzyżaniakowa, Jadwiga and Jerzy Ochmański. Władysław II Jagiełło. Wrocław, Warszawa, Kraków: Zakład Narodowy im. Ossolińskich, 2006.

Kuchkin, Vladimir A. "Russkiye knyazhestva i zemli pered kulikovskoy bitvoy." In $\mathrm{Ku}$ likovskaya bitva. Sbornik statey, edited by Lyubomir G. Beskrovnyy, 26-111. Moskva: Nauka, 1980.

Kuchkin, Vladimir A. “Tri zaveshchaniya Vasiliya I.” Drevnyaya Rus’. Voprosy mediyevistiki (2016) issue 2 (64): 33-54.

Kuczyński, Stefan M. Król Jagiełło ok. 1351-1434. Katowice: Wydawnictwo Ministerstwa Obrony Narodowej, 1985.

Kutrzeba, Stanisław and Władysław Semkowicz, eds. Akta unij Polski z Litwa, 1385-1791. Kraków: Polska Akademia Umiejętności, Towarzystwo Naukowe Warszawskie, 1932.

Lavrent'ev, Aleksandr. Posle Kulikovskoy bitvy. Ocherki istorii Oksko-Donskogo regiona v posledney chetverti XIV - pervoy chetverti XVI vv. Moskva: Kvadriga, 2011.

Likhachev, Dmitriy, ed. Slovar' knizhnikov i knizhnosti drevney Rusi, vol. 2/2. Leningrad: Nauka, 1989. 
Litskevich, Oleg B. 'Letopisets velikikh knyazey litovskikh' i 'Povest o Podol'ye.' Opyt kompeksnogo kriticheskogo razbora. Sankt-Peterburg: Izdatel'stvo Dmitriy Bulanin, 2019.

Lur'ye, Yakov S. "Moskovskiy svod 1479 goda i yego protograf." Trudy Otdela drevnerusskoy literatury 30 (1976): 95-113.

Lur'ye, Yakov S. Dve istorii Rusi XV veka. Ranniye i pozdniye, nezavismyye i ofitsial'nyy eletopisi ob obrazovanii Moskovskogo gosudarstva. Sankt-Peterburg: Izdatel'stvo Dmitriy Bulanin, 1994.

Łowmiański, Henryk. Polityka Jagiellonów. Poznań: Wydawnictwo Poznańskie, 1999.

Maciejewska, Wanda. "Dzieje ziemi połockiej w czasach Witołda." Ateneum Wileńskie 8 (1933): 1-56.

Miklosich, Franz and Joseph Müller, eds. Acta Patriarchatus Constantinopolitani MCCCXV-MCCCCII, vol. 2. Vindobonae: Carolus Gerold, 1862.

Mirgaleyev, Il'nur. Politicheskaya istoriya Zolotoy Ordy perioda pavleniya Toktamysh-khana. Kazan': Institut Istorii AN RT, 2003.

Nikodem, Jarosław. "Jedynowładztwo czy diarchia? Przyczynek do dziejów ustroju Wielkiego Księstwa Litewskiego do końca XIV w.” Zapiski Historyczne 68/4 (2003): 7-30.

Nikodem, Jarosław. “Rola Skirgiełły na Litwie do roku 1394.” Scripta Minora 2 (1998): 83-129.

Nikodem, Jarosław. Witold. Wielki Książe Litewski (1354 lub 1355 - 27 października 1430). Kraków: Wydawnictwo Avalon, 2013.

Paszkiewicz, Henryk. O genezie i wartości Krewa. Warszawa: Gebethner i Wolf, 1938.

Pietkiewicz, Krzysztof. Paleografia ruska. Warszawa: Wydawnictwo DiG, 2015.

Pochekayev, Roman. Tsari ordynskiye. Biografii khanov i praviteley Zolotoy Ordy. Sankt-Peterburg: Yevraziya, 2010.

Polechow, Siergiej. "Itinerarium wielkiego księcia litewskiego Witolda: 4/5 sierpnia 1392 - 2 października 1430.” Rocznik Lituanistyczny 5 (2019): 9-120.

Polekhov, Sergey. "Wielkie Księstwo Litewskie i Królestwo Polskie za czasów Jagiełły i Witolda w latopisarstwie ruskim." Zeszyty Naukowe Uniwersytetu Jagiellońskiego. Prace Historyczne 141/2 (2014): 583-597.

Polekhov, Sergey. Nasledniki Vitovta. Dinasticheskaya voyna $v$ Velikom knyazzhestve Litovskom v 30-ye gody XV veka. Moskva: Indrik, 2015.

Polnoye sobranie russkiikh' letopisey, vol. 8: Prodolzheniye letopisi po voskresenskomu spisku. Moskva: Yazyki Russkoy Kul'tury, 2001.

Polnoye sobranie russkiikh' lětopisey, vol. 11: Lětopisnyy sbornik' imenuyemyy patriarsheyu ili nikonovskoyu lětopis’yu. Sankt-Peterburg: Tipografiya I. I. Skorokhodova, 1897.

Polnoye sobranie russkiikh' letopisey, vol. 15: Rogozhskiy letopisets. Tverskoy sbornik. Moskva: Yazyki Russkoy Kul'tury, 2000.

Polnoye sobranie russkiikh' letopisey, vol. 17: Zapadnorusskiye letopisi. Moskva: Yazyki slavyanskikh kul'tur, 2008.

Polnoye sobranie russkiikh' lětopisey, vol. 23: Yermolinskaya lětopis’. Sankt-Peterburg: Tipografiya M. A. Aleksandrova, 1910. 
Polnoye sobranie russkiikh’ lětopisey, vol. 25: Moskovskiy letopisnyy svod kontsa XV veka. Moskva, Leningrad: Izdatel'stvo Akademii Nauk SSSR, 1949.

Polnoye sobranie russkiikh' lětopisey, vol. 28: Letopisnyy svod $1479 \mathrm{~g}$. Letopisnyy svod $1518 \mathrm{~g}$. (Uvarovskaya letopis'). Moskva, Leningrad: Izdatel'stvo Akademii Nauk SSSR, 1962.

Presnyakov', Aleksandr. Obrazovanie velikorusskago gosudarstva. Ocherk po istorii XIII-XV stolětiy. Petrograd': Tipografiya Ya. Bashmakov', 1918.

Prisëlkov, Mikhail D. Troitskaya letopis'. Rekonstruktsiya teksta. Sankt-Peterburg: Nauka, 2002.

Prochaska, Antoni. "Przyczynki krytyczne do dziejów Unii." Rozprawy Akademii Umiejętności. Wydział Historyczno-Filozoficzny 33 (1896): 55-122.

Prochaska, Antoni. “Upadek Kiejstuta." Kwartalnik Historyczny 23/4 (1909): 493-506.

Prochaska, Antoni. Dzieje Witolda Wielkiego Księcia Litwy. Kraków: Universitas, 2008.

Pushkarëva, Natal'ya L. Zhenshchiny drevney Rusi. Moskva: Mysl', 1989.

Rowell, Stephen C. Pogańskie imperium. Litewska dominacja w Europie Środkowo-Wschodniej 1295-1345. Translated by Grzegorz Smółka. Oświęcim: Napoleon V, 2017.

Russkaya istoricheskaya biblioteka, vol. 6: Pamyatniki drevne-russkago kanonicheskago prava. Sanktpeterburg: Tipografiya Imperatorskoy Akademii Nauk', 1880.

Salamon, Maciej. "Cyprian (Kyprianos, Kiprian) the Metropolitan of Kiev and Byzantine Policy in East-Central Europe." In Byzantium and East Central Europe, edited by Günter Prinzing, Maciej Salamon and Paul Stephenson, 221-235. Kraków: Towarzystwo Wydawnicze „Historia Iagellonica”, 2001.

Salamon, Maciej. "Fundacja klasztoru benedyktynów słowiańskich na Kleparzu. Ekumenizm w dobie św. Królowej Jadwigi." In Kościót krakowski w życiu państwa i narodu polskiego, edited by Andrzej Pankowicz, 61-82. Kraków: Wydawnictwo Naukowe Papieskiej Akademii Teologicznej, 2002.

Shabul'do, Feliks. Zemli yugo zapadnoy Rusi v sostave Velikogo Knyazhestva Litovskogo. Kiyev: Naukova dumka, 1987.

Skrzypek, Józef. Południowo-wschodnia polityka Polski od koronacji Jagiełty do śmierci Jadwigi i bitwy nad Worskla (1386-1399). Oświęcim: Napoleon V, 2015.

Sokołowski, August and Józef Szujski, eds. Codex epistolaris saeculi decimi quinti, vol. 1. Cracoviae: Akademia Umiejętności, 1876.

Solov'yëv, Sergey M. Drevnerusskiye knyazya. Sankt-Peterburg: Nauka, 2010.

Strehlke, Ernst, ed. "Johanns von Posilge, Officials von Pomesanien Chronik des Landes Preussen (von 1360 an, fortgesetzt bis 1419).” In Scriptores rerum Prussicarum, vol. 3, edited by Theodor Hirsch, Max Töppen and Ernst Strehlke, 79-388. Leipzig: S. Hirzel, 1866.

Tęgowski, Jan. "W sprawie genezy unii Polski z Litwą. Projekt małżeństwa Jagiełły z córką Dymitra Dońskiego wielkiego księcia moskiewskiego - próba ustalenia daty." Prace Naukowe Akademii im. Jana Długosza w Częstochowie 10 (2009): 51-64.

Tęgowski, Jan. “Zagadnienie władzy w Wielkim Księstwie Litewskim w okresie między unią krewską a zgonem Skirgiełły (1385-1394)." Zapiski Historyczne 66/4 (2001): $7-18$. 
Tęgowski, Jan. Pierwsze pokolenia Giedyminowiczów. Poznań, Wrocław: Wydawnictwo Historyczne, 1999.

Wigand von Marburg. Nowa kronika pruska. Edited by Sławomir Zonenberg and Krzysztof Kwiatkowski. Toruń: Towarzystwo Naukowe w Toruniu, 2017.

Wyrozumski, Jerzy. "Sprawa Rusi Halicko-Włodzimierskiej i Podola w stosunkach polsko-węgierskich wczesnej epoki jagiellońskiej.” In Węgry-Polska w Europie Środkowej. Historia - literatura. Ksiega pamiątkowa ku czci Profesora Wacława Felczaka, edited by Antoni Centarowicz, Csaba Kiss and István Kovács, 43-50. Kraków: Instytut Historii Uniwersytetu Jagiellońskiego, 1997.

Żdan, Michał. "Stosunki litewsko-tatarskie za Witolda." Ateneum Wileńskie 7/3-4 (1930): 529-601.

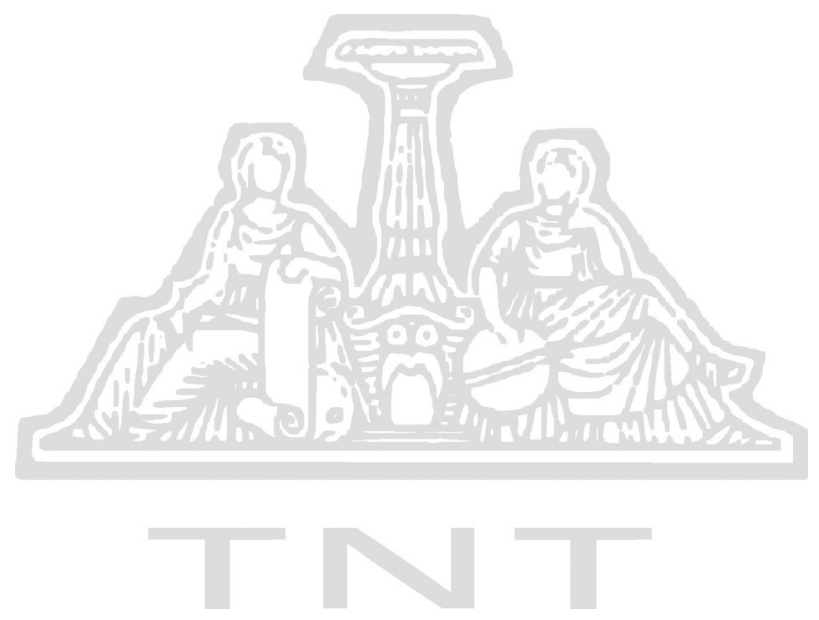

